\title{
Management of subclinical hypothyroidism in pregnancy: are we too simplistic?
}

\author{
Georg Brabant ${ }^{1,2}$, Robin P Peeters ${ }^{3}$, Shiao Y Chan ${ }^{4}$, Juan Bernal ${ }^{5,6}$, \\ Philippe Bouchard7, Domenico Salvatore ${ }^{8}$, Kristien Boelaert ${ }^{9}$ and Peter Laurberg ${ }^{10}$ \\ ${ }^{1}$ Experimental and Clinical Endocrinology, University of Lübeck, Ratzeburger Allee 160, D-23538 Lübeck, Germany, \\ ${ }^{2}$ Department of Endocrinology, University of Manchester, Manchester, UK, ${ }^{3}$ Department of Internal Medicine, \\ Rotterdam Thyroid Center, Erasmus Medical Center, Rotterdam, The Netherlands, ${ }^{4}$ Department of Obstetrics and \\ Gynaecology, National University of Singapore, Singapore, Singapore, ${ }^{5}$ Instituto de Investigaciones Biomedicas, \\ Consejo Superior de Investigaciones Cientificas and Universidad Autonoma de Madrid, Madrid, Spain, \\ ${ }^{6}$ Center for Biomedical Research on Rare Diseases, Madrid, Spain, ${ }^{7}$ Pierre et Marie Curie University, Paris, France, \\ ${ }^{8}$ Department of Clinical Medicine and Surgery, University of Naples 'Federico II', Naples 80131, Italy, \\ ${ }^{9}$ College of Medical and Dental Sciences, Institute for Biomedical Research, Centre for Endocrinology, Diabetes and \\ Metabolism, Level 2, University of Birmingham, Birmingham B15 2TT, UK and ${ }^{10}$ Department of Endocrinology, \\ Institute of Clinical Medicine, Aalborg University Hospital, Aalborg University, Aalborg, Denmark
}

Correspondence
should be addressed
to G Brabant
Email
georg.brabant@uksh.de

\begin{abstract}
Guideline advice of many societies on the management of subclinical hypothyroidism in pregnancy suggests treatment when TSH serum levels exceed $2.5 \mathrm{mU} / \mathrm{l}$. Justification of this procedure is based on limited experience, mainly from studies carried out in patients with positive thyroid-specific antibodies and higher TSH levels that classically define the condition in the nonpregnant state. Taking into account a lack of clear understanding of the regulation of thyroid hormone transport through the utero-placental unit and in the absence of foetal markers to monitor the adequacy of thyroxine treatment, this review attempts to discuss currently available data and suggests a more cautious approach.
\end{abstract}

\section{Current guideline aims and epidemiology}

Management of overt hypothyroidism $(\mathrm{OH})$ and subclinical hypothyroidism $(\mathrm{SCH})$ in pregnancy has been systematically reviewed in the guidelines of several societies: The American Endocrine Society (TES), the American Thyroid Association (ATA) jointly with the American Association of Clinical Endocrinologists (AACE) and most recently by the European Thyroid Association (ETA) $(1,2,3,4)$. $\mathrm{OH}$ diagnosed during pregnancy requires immediate treatment with thyroid hormones (THs), which is undisputed in order to avoid the potentially devastating effects of hypothyroidism on cognitive function of the offspring and to reduce pregnancy-associated risks to the foetus and the mother (5). In all these guidelines, there is also consensus that SCH - defined as serum thyroidstimulating hormone (TSH) concentrations above $2.5 \mathrm{mU} / 1$ (preconception and in the first trimester) with normal (c) 2015 European Society of Endocrinology Printed in Great Britain circulating TH levels - should be treated with levothyroxine ( $\mathrm{L}-\mathrm{T}_{4}$ ) replacement. In addition, isolated hypothyroxinaemia (normal TSH and reduced free thyroxine ( $\mathrm{fT}_{4}$ ) concentrations) is regarded as a different entity, which will not be further discussed in depth in this manuscript.

The TES guideline targets both $\mathrm{SCH}$ patients who are TPO-Ab negative and those who are TPO-Ab positive (1.2.2 TES guideline), rating the evidence to treat as poor to fair but states that 'potential benefits outweigh the potential risks' (2). ATA/AACE guidelines also suggests treatment of all SCH pregnant women regardless of the antibody status when TSH serum concentrations exceed the pregnancyspecific upper limits of $2.5 \mathrm{mU} / 1$ in the first trimester and 3.0 or $3.5 \mathrm{mU} / 1$ in the following trimesters respectively (1). All guidelines agree that 'it is reasonable practice to maintain TSH values in women planning pregnancy below $2.5 \mathrm{mU} / \mathrm{l}$, especially in those with positive TPO-Ab;

Published by Bioscientifica Ltd. 
newly diagnosed patients should be treated in order to normalise maternal serum TSH values within the trimester-specific pregnancy reference range (3)'. The recent ETA guideline, which generally agreed on a TSH threshold of $>2.5 \mathrm{mU} / \mathrm{l}$ for starting $\mathrm{T}_{4}$ substitution, has discussed this question even more controversially by stating that 'the debate about substitution therapy in $\mathrm{SCH}$ is still open both for non-pregnant and pregnant patients', but remained in favour of treatment because the panel believed that ' $\mathrm{T}_{4}$ treatment of $\mathrm{SCH}$ would appear to have the potential benefits which outweigh the potential risks' (3).

Since the first publication of a specific guideline on the management of thyroid dysfunction in pregnancy by TES in 2007 (6), major changes in clinical practice have been observed in many countries. Screening, generally discussed as an open question (3), is now a reality in many countries and close surveillance of TSH with an upper threshold of $2.5 \mathrm{mU} / \mathrm{l}$ now drives treatment primarily by gynaecologists and centres for reproductive medicine. A clear benefit of screening has been an increase in the detection rate of thyroid dysfunction which helps to improve the well-recognised problem of undetected $\mathrm{OH}$ (7). The rate of $\mathrm{OH}$ varied between 0.25 and $0.91 \%$ in large population studies carried out in a total of 104557 participants $(7,8,9)$, whereas screening has also resulted in the diagnosis of $\mathrm{SCH}$ in $3-10 \%$ of pregnancies, depending on the TSH cut-off and assay platform used $(9,10)$. A recent Chinese study $(11)$ has reported that up to $30 \%$ of pregnant women in early pregnancy were classed as having SCH if the generic cut-off of $2.5 \mathrm{mU} / 1$ was used. Not all of them will have thyroid disease, as a recent investigation in completely healthy non-pregnant young women from Denmark suggests that $10-15 \%$ spontaneously have TSH levels $>2.5 \mathrm{mU} / \mathrm{l}$ (12). Furthermore, a study carried out in healthy, pregnant, iodine sufficient (13) women from The Netherlands showed that $>10 \%$ of TPO-Ab-negative women had a TSH level above $2.5 \mathrm{mU} / 1$ in the first trimester.

Here we would like to discuss the pathophysiological basis of interventions in $\mathrm{SCH}$ and the currently available markers for monitoring mother and offspring during the management of SCH to add some caution to the current approach.

\section{Changes of TSH, THs and iodine during pregnancy}

Normal pregnancy has profound impacts on thyroid function. Placental production of human chorionic gonadotrophin (hCG) and a rise in oestrogen production that increases binding proteins, namely thyroxinebinding globulin affect free TH levels. TSH dips according to most but not all studies within the first trimester, whereas free $\mathrm{TH}$ concentrations decrease, albeit very slightly, mainly during the latter part of pregnancy $(10,11,14,15,16,17,18,19)$. These observed alterations are not only due to pathophysiological changes but are, at least in part, due to methodological issues.

Placental production of hCG alters circulating TSH concentrations because hCG at high concentrations acts as an activator of the TSH receptor $(14,15)$. hCG's rapid increase in the first trimester of pregnancy is therefore viewed as being essential for a higher synthesis and release of $\mathrm{T}_{4}$ from the thyroid. Another crucial factor that can alter TSH levels in pregnancy is iodine availability. From early pregnancy, renal clearance of iodine is reported to increase (20), in parallel with the increase in glomerular filtration rate (21). This may profoundly impact on the sensitivity or responsiveness of the thyroid to TSH and hence $\mathrm{TH}$ release. Experimental evidence suggests that, in humans, TSH decreases but thyroglobulin increases in mild iodine deficiency (22). Detailed animal studies as well as data obtained for humans on the uptake of radioactive iodine indicate that in nutritional iodine deficiency there is an increased sensitivity of the thyroid to TSH, resulting in most of the follicles being actively involved in thyroid function. This is in contrast to the thyroid exposed to normal dietary iodine supply, where only scattered, solitary follicles are active $(23,24,25)$. A recent large epidemiological study carried out in children and adolescents supports this notion of the fine tuning of thyroidal TSH-responsiveness by iodine as TSH concentrations were decreased with circulating TH concentrations maintained in iodine deficiency (26).

In pregnancy, a similar delicate adaptation of the maternal thyroid function may take place. Comparable to the above mentioned studies, a decrease in iodine availability - as anticipated by the increased renal clearance of iodine in pregnancy - may contribute to the decrease in maternal TSH levels in early pregnancy. This would explain some epidemiological data supporting a positive correlation between TSH level and urinary iodine concentration $(16,27,28)$, but is contradicted in a large cross-sectional Chinese study conducted for measuring TSH and iodine excretion within the first trimester of pregnancy, showing that serum TSH concentrations did not differ in non-pregnant women during the first 6 weeks of pregnancy, but only between weeks 7 and 12 of pregnancy a significant decrease was found (11). 
Interestingly, these changes were independent from urinary iodine excretion, which indicated adequate iodine supply and were comparable between pregnant and nonpregnant women.

The depth, rate and timing of the first-trimester dip in TSH scatter widely between studies and with marked interindividual variability within studies $(10,14,15,17$, 18, 19). Methodological differences amongst TSH assay platforms may explain some of the variation. A recently published comparison of seven different frequently used assay systems for $\mathrm{TSH}$ and $\mathrm{fT}_{4}$ in samples obtained in the first trimester of pregnancy revealed a more than $40 \%$ variation between assay results of the same sera suggesting that a firm cut-off of $2.5 \mathrm{mU} / 1$ in one assay may correspond to a higher level with another, sometimes by as much as $1 \mathrm{mU} / \mathrm{l}$ or more (29). The calculation of assay-specific multiples of the median (MoM) values may overcome these limitations as recently proposed, and may better homogenise the assay variations (30). This, however, relies on the availability of assay-specific normative data, frequently demanded but very rarely instituted in every day practice.

In addition to assay variations, other population characteristics such as iodine intake, ethnicity and BMI likely contribute to these substantial differences in TSH between different populations. A recent multi-ethnic population-based pregnancy cohort from European origin has shown substantial differences in the upper limits of TSH (as determined by the 97.5th percentile in TPO-Ab negative women) between different ethnic groups. For example the upper limit of TSH was $4.18 \mathrm{mU} / 1$ in women from Dutch origin compared with $3.58 \mathrm{mU} / 1$ in women living in the same region but from Moroccan origin (31). In a Scandinavian study, women with a BMI $<20 \mathrm{~kg} / \mathrm{m}^{2}$ showed that the upper limit (P95) for TSH increased from 2.86 to $3.50 \mathrm{mU} / 1$ compared with women with a BMI $>30 \mathrm{~kg} / \mathrm{m}^{2}$ (32).

The magnitude of decrease of free TH levels during the course of pregnancy is subject to high variability as well (33). This may in part be explained by a variable impact of pregnancy-associated changes in binding proteins on the different assay systems as tested by Feldt-Rasmussen et al. (34). When calculating MoM, this variability is much lower with a consistent decrease in $\mathrm{fT}_{4}$ from the first to third trimesters of pregnancy by $\sim 20 \%$, with extremes of 10 and $30 \%$ respectively. Only the measurement of $\mathrm{T}_{4}$ with tandem mass-spectrometry, currently regarded as the gold standard, shows a much greater decrease in $\mathrm{fT}_{4}$ by $\sim 50 \%$ (35).

The mechanisms behind these changes and their relevance to the control of foetal $\mathrm{TH}$ homeostasis have not been fully elucidated. They may be driven by a lower availability of free $\mathrm{TH}$ in the maternal circulation due to the altered binding protein expression and an increased $\mathrm{TH}$ metabolism driven by the placental expression of deiodinase type 3 (D3), as well as by an increasing transfer of THs to the foetus with advancing gestation.

\section{Evidence for adverse effects of SCH during pregnancy}

Careful assessment of the existing literature in the framework of all guidelines left no doubt that untreated or inadequately treated $\mathrm{OH}$ leads to an array of pregnancy complications, namely preeclampsia, gestational hypertension, cretinism, foetal death and spontaneous miscarriage (36). Despite those, several reports of severe $\mathrm{OH}$ did not show an increased rate of pregnancy-related complications, suggesting that even severe hypothyroidism does not necessarily preclude normal pregnancy outcomes nor induce complications (37).

What is the evidence for adverse effects of $\mathrm{SCH}$ in pregnancy? Based on the cited literature in the guidelines, a range of effects is described, but the number of affected cases in most studies is small and data are not consistent when focusing on various aspects of pregnancy complications. It is beyond the scope of this paper to discuss all studies investigating these different pregnancy complications in detail. For this reason, we will predominantly focus on miscarriage rate as one of the beststudied pregnancy complications. The diversity in results is highlighted in two studies on the miscarriage rate in $\mathrm{SCH}$. One was a prospective investigation of the rate of pregnancy loss in TPO-negative women with TH concentrations within the classically defined non-pregnant normal range (38). The percentage of miscarriage was almost doubled when TSH in the first trimester of pregnancy was between 2.5 and $5 \mathrm{mU} / 1$ as compared with a TSH $<2.5 \mathrm{mU} / 1$. In absolute numbers, it was based on 39 pregnancy losses of 642 pregnancies $(6.1 \%)$ in the TSH of range $2.5-5.0 \mathrm{mU} / 1$ group as compared with 127/3481 (3.6\%) in pregnancies with TSH below $2.5 \mathrm{mU} / 1$. However, in another larger prospective study of 240 patients with $\mathrm{SCH}$ and TSH concentrations $>4.29 \mathrm{mU} / 1$ with normal $\mathrm{TH}$ concentrations, there was no difference in miscarriage rate as compared with almost 10000 healthy controls. Eightyfive percent of these patients were TPO-Ab negative and there was no difference in any other pregnancy-associated complications (39). The problems of comparisons between studies are highlighted in a recent meta-analysis showing a wide scatter in the definitions of $\mathrm{SCH}$, the population characteristics including iodine status as well as the timing of recruitment and testing across 16 studies with a total of 
2573 cases of SCH in 49545 pregnancies (9). Not all studies reported an increased miscarriage rate.

What are potential alternative explanations for the reported differences in pregnancy outcomes? One possibility is the associated immune dysfunction commonly seen in autoimmune conditions. The rate of miscarriage is believed to be higher in patients with a positive history of autoimmune disease, not just of thyroid origin but also in diagnoses such as systemic lupus erythematosus (SLE) and type 1 diabetes. In a recent meta-analysis by Thangaratinam et al. (40), the rate of pregnancy complications has been linked to thyroid autoimmunity showing significantly higher rates of complications in antibody positive women than in antibody negative controls, despite biochemical euthyroidism. Interaction of TSH receptor autoantibodies with receptors for gonadotrophins may represent one mechanism to explain the increased prevalence of problems in pregnancies of mothers with autoimmune thyroid disease, but a number of other mechanisms including associated immune dysregulation targeting particularly the reproductive tract and/or the foeto-placental unit have been discussed $(41,42)$. This is confirmed by a recent larger prospective study that has shown a stepwise increase in miscarriage rates with thyroid autoimmunity alone and in combination with SCH (43).

Despite these findings, the frequency of miscarriage reported in smaller studies is difficult to judge against expectations from large population-based investigations because data on the frequency of miscarriage in the first weeks of pregnancy vary considerably. More than $70 \%$ of pregnancies may spontaneously miscarry within the first 6 weeks (a significant proportion unnoticed) and the prevalence thereafter is given as $\sim 10 \%$, depending on factors including the time from conception, age or ethnicity (44). Hence many existing studies have underestimated miscarriage rates as a recruitment that typically begins after 6 weeks gestation. Hopefully this problem, which is common to all existing studies, will be substantially improved by the ongoing TABLET and T4LIFE RCTs which recruit and randomise TPO-Ab positive women preconception and will provide highquality prospective data on miscarriage rates as well as the efficacy of $\mathrm{T}_{4}$ treatment in the future (9).

\section{What is the therapeutic evidence for benefits following normalisation of thyroid function during pregnancy?}

There are only few outcome data on $\mathrm{L}^{-} \mathrm{T}_{4}$ treatment in $\mathrm{SCH}$, with and without TPO-Ab positivity, during pregnancy.
Amongst the published studies, treatment was initiated at different TSH thresholds; some in subjects with TSH concentrations even lower than the proposed threshold of $2.5 \mathrm{mU} / 1$ and others with TSH concentrations $>4.5 \mathrm{mU} / \mathrm{l}$. In one study, 984 pregnant women were screened to identify 115 euthyroid pregnancies with normal TSH but with TPO-Ab positive, who were then divided into a $\mathrm{T}_{4}$-treated group and a control group, recruited at a mean gestation of 10 weeks and followed up until delivery. Mean TSH at the start of the intervention was comparable in the $\mathrm{T}_{4}$-treated intervention group (TSH $1.6 \mathrm{mU} / \mathrm{l} ; 57 \mathrm{TPO}-\mathrm{Ab}$-positive subjects) and the TPO-positive controls (TSH $1.7 \mathrm{mU} / \mathrm{l} ; 58$ TPO-positive subjects), whereas in the TPO-Ab-negative control cohort, TSH was even lower (TSH $1.1 \mathrm{mU} / \mathrm{l} ; n=869$ ). The mean $\mathrm{T}_{4}$ dose was $49.7 \mu \mathrm{g} /$ day in the intervention group, which resulted in significantly lower TSH levels than that in the TPO-Ab-positive controls. Miscarriage rate was described as significantly lower in the treated group and equivalent to the TPO-Ab-negative controls (45). However, the mean gestational age of starting $\mathrm{L}_{-} \mathrm{T}_{4}$ was estimated to be 10 weeks, and all but one of the miscarriages occurred at $<11$ weeks.

A Belgian study of TPO-Ab positive, treatment naïve patients which compared them to a $\mathrm{T}_{4}$-treated group revealed a miscarriage rate of $0 / 34$ in subjects treated with $50 \mu \mathrm{g} /$ day of $\mathrm{T}_{4}$ during pregnancy as compared with $5 / 31$ in untreated subjects. Serum TSH levels in both groups were, however, marginally different with a mean of $1.61 \mathrm{mU} / 1$ in the untreated group vs $1.05 \mathrm{mU} / 1$ in treated participants, albeit all within the normal range (46). In another small prospective, randomised trial in patients undergoing assisted reproduction which included those with slightly higher serum TSH concentrations, who were treated with $50-100 \mu \mathrm{g} \mathrm{T}_{4}$ /day from preconception (average mean TSH was $1.1 \mathrm{mU} / \mathrm{l}$ vs $4.9 \mathrm{mU} / \mathrm{l}$ in the untreated control group), the miscarriage rate appeared higher in controls than that in treated patients (47). It has to be borne in mind that the real comparison of miscarriage rate is based on the number of pregnancies achieved, which leaves the study with even lower numbers (three miscarriages out of 12 in the $\mathrm{T}_{4}$ group vs four out of five control pregnancies). This is in contrast with an investigation in women suffering from recurrent pregnancy loss. Focusing on live birth rates, there was no difference in the outcome between euthyroid patients $(n=141)$ and patients with $\mathrm{SCH}$ $(n=39)$. There was also no difference between treated $(n=24)$ and untreated $(n=15)$ SCH subjects (48). In a prospective randomised trial of 64 infertile patients with 
SCH undergoing controlled ovarian stimulation for IVF/ICSI, a $\mathrm{T}_{4}$ therapy arm (initial TSH $6.6 \mathrm{mU} / \mathrm{l}$ ) and a control group (initial TSH $6.7 \mathrm{mU} / \mathrm{l}$ ) were formed ( $~ 80 \%$ in both groups were TPO-Ab positive). None of the patients were treated with $50 \mu \mathrm{g} / \mathrm{day}_{4}$, but four of the untreated pregnancies ended in miscarriage, and the embryo implantation rate as well as live birth rate was significantly higher in the $\mathrm{L}^{-} \mathrm{T}_{4}$ treatment group; importantly, the TPO-Ab concentrations were also significantly higher in the control group (49) (for overview of all mentioned studies see Table 1 ).

There are several studies that shed some light on the impact of TH therapy on pregnancy complication rates, but these studies were not designed to judge the efficacy of therapy on pregnancy outcomes (50). This equally applies to the largest completed prospective study thus far to evaluate the efficacy of $\mathrm{T}_{4}$ treatment on the neurophysiological outcome in the offspring (CATS trial). This trial evaluated, as a secondary outcome, pregnancy complications in maternal thyroid hypofunction, including $\mathrm{SCH}$ (TSH above the 97.5th percentile and/or $\mathrm{fT}_{4}$ below the 2.5 th percentile) before 16-week pregnancy (51). A total cohort of 21846 women was screened and 1050 (4.8\%) fulfilled the study criteria; 404 women were in the untreated control group, whereas 390 received $\mathrm{T}_{4}$ treatment. As pregnancy-related complications were not the primary outcome of the study, the results published are not detailed in this respect. However, they concluded that 'no significant differences between the screening and control groups were observed with respect to gestational age at delivery (median, 40.1 and 40.2 weeks, respectively;
$P=0.10)$, rates of preterm birth $(<37$-week gestation, 5.6 and $7.9 \% ; P=0.20$ ) and birth weight (mean, 3.5 and $3.3 \mathrm{~kg} ; P=0.15)^{\prime}$.

Furthermore, treatment with $\mathrm{T}_{4}$ does not necessarily result in an euthyroid state. A recent, retrospective analysis of 1013 pregnant women on $\mathrm{T}_{4}$ medication demonstrated that only $37.1 \%$ of the patients were within the target range of $0.2-2.5 \mathrm{mU} / \mathrm{l}, 6.5 \%$ overtreated and $56.4 \%$ undertreated. The possible impact of miscarriage rates secondary to overtreatment cannot be judged due to the low numbers, but there was a significant association between miscarriage and increased TSH levels above the target TSH range of $0.2-2.5 \mathrm{mU} / \mathrm{l}$. This was largely due to the disproportionate impact of cases where the TSH was $>10 \mathrm{mU} / \mathrm{l}$, but significantly increased already when TSH was $>4.5 \mathrm{mU} / \mathrm{l}$ (52). Similarly, another small study suggested more miscarriages with both suppressed and elevated TSH in pregnant women on $\mathrm{T}_{4}$ replacement (53).

In summary, all these studies are hampered by the low number of patients, by wide heterogeneity and by the fact that in some studies treatment was initiated despite a seemingly normal TSH concentration at the start of treatment.

\section{Utero-placental unit and TH homeostasis}

The utero-placental unit is the maternal-foetal interface that consists of genetically different maternal and foetal cells whose activities are modulated by a complex network of cellular crosstalk involving the local release of hormones, cytokines, chemokines and growth factors.

Table 1 Overview of studies on the effects of thyroxine treatment on miscarriage rate in pregnancy.

\begin{tabular}{|c|c|c|c|c|c|c|}
\hline Study & Study design & $\begin{array}{l}\text { Initial TSH }(\mathrm{mU} / \mathrm{l}) \\
\text { (control vs } \mathrm{T}_{4} \text { ) }\end{array}$ & $\begin{array}{l}\text { Dose of thyroxine } \\
(\mu \mathrm{g} / \text { day) }\end{array}$ & $\begin{array}{l}\text { Thyroid } \\
\text { autoimmunity }\end{array}$ & $\begin{array}{c}\text { Miscarriage rate/ } \\
\text { group size } \\
\left(\text { control vs } \mathrm{T}_{4}\right)\end{array}$ & References \\
\hline Negro et al. & $\begin{array}{l}\text { Prospective } \\
\text { Randomised }\end{array}$ & $\begin{array}{l}1.7 \text { vs } 1.6 \text { at week } \\
10\end{array}$ & 0 vs $49.7 \pm 14$ & Yes & $8 / 58$ vs $2 / 57$ & $(45)$ \\
\hline Lepoutre et al. & $\begin{array}{l}\text { Retrospective } \\
\text { Non-randomised }\end{array}$ & $\begin{array}{l}1.61 \text { vs } 1.05 \text { first } \\
\text { trimester }\end{array}$ & $\begin{array}{l}0 \text { vs } 50 \text { with dose } \\
\text { titration }\end{array}$ & Yes & $5 / 31$ vs $0 / 34$ & (46) \\
\hline Wang et al. & $\begin{array}{l}\text { Prospective } \\
\text { Non-randomised }\end{array}$ & $\begin{array}{l}>2.5 \text { before } \\
\text { week } 12\end{array}$ & $\begin{array}{l}\text { 50-100, not } \\
\text { specified }\end{array}$ & Not reported & $26 / 168$ vs $2 / 28$ & $(47)$ \\
\hline $\begin{array}{l}\text { Abdel-Rahman } \\
\text { et al. }\end{array}$ & $\begin{array}{l}\text { Prospective } \\
\text { Randomised }\end{array}$ & $\begin{array}{l}4.8 \text { vs } 4.7 \\
\text { IVF } \\
\mathrm{T}_{4} \text { started before } \\
\text { IVF }\end{array}$ & $\begin{array}{l}0 \text { vs } 50-100 \text { with } \\
\text { dose titration }\end{array}$ & Not determined & $4 / 5$ vs $3 / 12^{a}$ & (80) \\
\hline Kim et al. & $\begin{array}{l}\text { Prospective, } \\
\text { randomised } \\
\text { IVF }\end{array}$ & $\begin{array}{l}6.7 \text { vs } 6.6 \\
\mathrm{~T}_{4} \text { started with } \\
\text { stimulation }\end{array}$ & 0 vs 50 & Both accepted & $4 / 12$ vs $0 / 17^{a}$ & (49) \\
\hline
\end{tabular}


This is key to preventing immune rejection of the foetus as well as ensuring adequate trophoblast invasion and placentation for effective nutritional and waste exchange. Defects in this delicate network and placentation may lead to pregnancy complications, such as miscarriage, preterm labour, pre-eclampsia and foetal growth restriction. The putative role of THs in this regulation is far from clear, but human data show that a range of $\mathrm{TH}$ transporters, TH-binding protein (transthyretin (TTR)), the deiodinases D2 and D3 as intracellular activators and inactivators of THs, as well as TH receptor isoforms, TR $\alpha 1$, TR $\alpha 2$, TRß1, are expressed in the key cellular components forming the placenta. The expression of the receptors increases with gestational age (54). Tri-iodothyronine $\left(\mathrm{T}_{3}\right)$ is able to alter the cytokine network in a cell-type and gestational agedependent manner in human utero-placental cells (55) and promote human trophoblast invasion (56).

Human placental tissue is able to produce TH-binding proteins such as TTR and albumin (57). These binding proteins may play an as yet undefined role in the regulation of TH levels and their vulnerability to placental degradation. The observation that high levels of TTR are present in foetal serum when foetal liver TTR mRNA expression is very low may suggest a placental origin (57). The human sodium iodide symporter (NIS) is detectable in villous placental tissue as early as 6 weeks of pregnancy, substantially increases to a peak during the first 12 weeks of pregnancy (58) and may be autoregulated by iodine availability (59).

TH transporters are able to regulate the availability of THs to placental tissue. They are expressed in various placental cell types, but their role in the regulation of placental development itself and the transfer of TH to the foetus are not completely understood. In studies on the microvillous plasma membrane of human term syncytiotrophoblasts, which are in direct contact with the maternal blood system, a wide variety of transporters have been characterised such as L-type amino acid transporter 1 and CD98, monocarboxylate transporter 8 (MCT8) and MCT10, organic anion-transporting polypeptide $1 \mathrm{~A} 2$ (OATP1A2) and OATP4A1 (60).

It is interesting to note that in the rat, which has a different type of placental system compared with the human, OATP1C1 and MCT8 regulation seem to be affected by nutritional iodine supply (61). Moderateto-severe iodine deficiency in the rat increases OATP1C1 in the period before the onset of foetal thyroid function (GD16), whereas a downregulation is observed thereafter (GD20). During this latter period MCT8 is upregulated.
Both D2 (involved in the activation of $\mathrm{T}_{4}$ to $\mathrm{T}_{3}$ ) and $\mathrm{D} 3$ (responsible for $\mathrm{TH}$ degradation) are expressed in placenta (62). Detailed studies in human placenta demonstrate that D3 is expressed in the maternal decidua, the syncytiotrophoblast layer (maternal aspect), the cytotrophoblasts (foetal aspect) and the foetal endothelium of the chorionic villi to control local $\mathrm{TH}$ concentrations (52). The expression of deiodinases on the maternal side of the placenta may have consequences also on maternal $\mathrm{TH}$ levels as we know from consumptive forms of hypothyroidism that high expression of D3 in tumour tissue may lead to a substantial decrease in TH concentrations even in adulthood (63). According to immunohistochemical studies in human placenta, there is lower D3 expression in cytotrophoblasts compared with syncytiotrophoblasts, whereas D2 expression is more prominent in cytotrophoblasts $(64,65)$.

High expression of D3 on the maternal side of the placenta is suggested to be more effective in protecting the foetus from exposure to temporally inappropriate concentrations of maternal THs. In addition, changes in the expression and action of multiple $\mathrm{TH}$ transporters within the placenta across gestation serve to regulate placental TH uptake and the transplacental passage of $\mathrm{TH}$ to the foetus $(60,66)$. Generally, placental D3 activity is $\sim 200$-fold greater than D2 making D3 the predominant deiodinase in placenta (57). Owing to its high degradation activity, D3 has a major impact on the availability of $\mathrm{T}_{3}$ to its specific receptors.

In mice, D2 is highly expressed in the uterus by days 3-4 of gestation and D3 is significantly induced in uterine stromal tissue immediately following implantation and is closely regulated by progesterone and also by substrate autoregulation where $\mathrm{T}_{3}$ stimulates D3 activity, suggesting that protection against local $\mathrm{T}_{3}$ elevations are critical in early pregnancy (62). Mice placental D3 activity decreases across pregnancy whereas D2 is upregulated at GD20 (61). The highest expression of D3 is found in the villous syncytiotrophoblast, suggesting an important function to control for variations in maternal TH concentrations. This is in part reflected in changes in maternal $\mathrm{TH}$ concentrations in healthy pregnancy, where levels of reverse $T_{3}$ to total $T_{3}$ reveal a clear shift with a sharp increase in the ratio from early in pregnancy and throughout pregnancy. The critical importance of $\mathrm{TH}$ degradation to protect the foetus from the detrimental effects of high TH levels in early embryonic development has been shown in D3-knockout mice, where offspring develop central hypothyroidism due to thyrotoxicosis in early development $(67,68)$. For the human, ex vivo 
placental perfusion studies have demonstrated significant $\mathrm{T}_{4}$ inactivation by D3 during transplacental passage (69), but data are still too incomplete to draw firm conclusions on the role of deiodinases, especially D3, in the regulation of maternal-to-foetal transfer of THs under normal conditions and in pathophysiological states.

\section{TH concentrations in the offspring}

Data on TH concentrations in the foetus during the course of pregnancy are scarce. In humans they are mainly based on blood sampled by cordocentesis. A relatively large study published back in 1991 established TSH and TH reference concentrations in 62 foetuses during the course of pregnancy, including blood obtained by cordocentesis before the 14th week of pregnancy, before endogenous foetal $\mathrm{TH}$ production. In all pregnancies, the investigation was performed for a suspected pathology, but only offspring normally developed for their gestational age with minor malformations such as polycystic kidney disease were included. In comparison with the parallel sampled maternal levels, TH concentrations in the foetus are much lower, particularly in the first part of pregnancy along with significantly higher foetal TSH levels (70) (Fig. 1).

The low levels of foetal THs in early pregnancy, confirmed by others, support the discussed high efficacy of placental regulation to optimise circulating $\mathrm{TH}$ levels for the foetal demands during the respective stage of pregnancy whilst allowing local activation of THs to satisfy independent spatial and temporal requirements of each tissue depending on the developmental stage (54). The continued transfer of THs from mother to foetus until delivery is exemplified in studies of athyreotic neonates
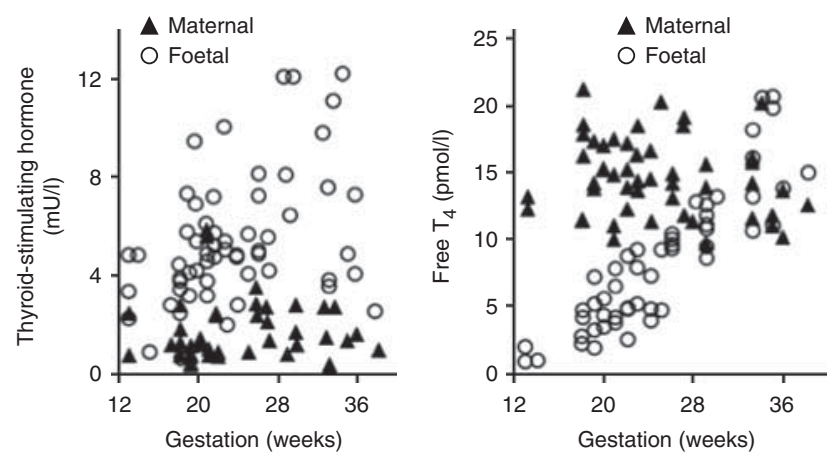

\section{Figure 1}

Maternal and foetal TSH and $\mathrm{fT}_{4}$ serum concentrations during pregnancy (70). at birth, which demonstrate that maternal TH transfer occurs and can enable them to reach TH concentrations of $\sim 50 \%$ of a normal neonate (71). In cases of intrauterine growth restriction or placental insufficiency, foetal $\mathrm{TH}$ levels are described to be lower than that in the reference population (72).

The effect of maternal $\mathrm{T}_{4}$ treatment on circulating foetal $\mathrm{TH}$ concentrations has recently been investigated. In mothers with autoimmune hypothyroidism $(n=25)$, the effect of $\mathrm{T}_{4}$ replacement was monitored by cordocentesis between weeks 22 and 33 of pregnancy (73). Despite treatment to euthyroidism in all but one hypothyroid mother, $60 \%$ of the foetuses showed higher than normal $\mathrm{fT}_{4}$ levels in blood obtained by cordocentesis (74). In another large study of 246 neonates of $\mathrm{T}_{4}$-treated mothers with known pre-existing hypothyroidism, both serum $\mathrm{fT}_{4}$ and TSH concentrations were found to be high within a few days of birth (59). Furthermore, the mean birth weight and head circumference were significantly lower than that in controls $(n=139)$. In view of data in healthy euthyroid mothers, where a significant positive correlation was observed between $\mathrm{fT}_{4}$ concentrations across the normal reference range (in cord blood at birth) and birth weight, these results could be viewed as a problem of insufficient supply with THs during pregnancy (75). On the contrary, it is well known that hyperthyroidism too may lead to foetal growth retardation. This phenomenon is not restricted to autoimmune thyroid dysfunction, but is shown in patients with activating TSH receptor mutations where premature labour and low birth weight are a consistent finding (76). This would fit the results of the recently published, Generation $\mathrm{R}$ study, which suggests that high maternal $\mathrm{fT}_{4}$ during the first trimester is associated with low birth weight indicating a much more complex relationship (77). Moreover, Danish registry studies have shown low birth weights in children born to mothers with hyperthyroidism, and high birth weight in hypothyroidism (78). Currently, we know very little about the effects of maternal $\mathrm{T}_{4}$ therapy on $\mathrm{TH}$ concentrations in the foetus and whether the additional $\mathrm{T}_{4}$ dosage is indeed transferred through a variably disturbed utero-placental unit.

\section{Summary and perspectives}

$\mathrm{SCH}$ in pregnant patients is not a clearly defined condition but a disorder in the grey zone between normality and pathophysiology, currently lacking any marker to predict effects on the foetus itself. Considerable efforts have been made to better define this condition, particularly aiming 
to identify the timing when therapeutic interventions with THs may be indicated. This has been summarised and formalised for non-pregnant conditions in guidelines from TES, ATA, AACE and most recently the ETA $(1,79)$. The methodological problems associated with measurements under non-pregnant conditions are accentuated in pregnancy. Thus, establishing a firm diagnosis of the condition may not be trivial in pregnancy. Furthermore, defining firm thresholds for treatment based on thyroid function tests - which is not trivial outside pregnancy - is much more challenging in pregnancy. Measurement of clinical outcomes including miscarriage, stillbirth, long-term cognitive function as well as risk of attention deficit hyperactivity or psychiatric disorders of the offspring require large sample sizes and may be confounded by many factors. Furthermore, the question of whether mild maternal dysfunction is the cause or the consequence of any malfunction of the utero-placental unit, or simply a confounding factor to other primary aetiologies such as an accompanying autoimmune disorder, remains largely open.

Currently, we lack any reliable non-invasive foetal marker to monitor the effects of maternal $\mathrm{T}_{4}$ therapy in routine clinical practice, except for foetal growth ultrasound scanning, which remains a relatively blunt instrument with poor sensitivity and specificity in this context. Our knowledge of the regulation of the transfer of THs across the utero-placental unit is in its infancy. It appears to be controlled by binding proteins such as TTR, various TH transporters activities, a highly efficient pre-receptor control based on D2 and D3 activities and the expression of different $\mathrm{TH}$ receptor subtypes. All of these regulatory mechanisms are currently incompletely understood. Despite these uncertainties, the marked differences between maternal and foetal TH concentrations suggest that the interplay of all these regulatory placental pathways is highly efficient to control foetal TH availability, particularly in the critical first weeks of pregnancy. With the lack of any reliable foetal markers to target $\mathrm{T}_{4}$ treatment within the framework of a highly regulated, complex barrier system between the maternal and foetal circulation, present data appear to be insufficient to support treatment of all pregnant women with a serum TSH level slightly above $2.5 \mathrm{mU} / \mathrm{l}$. It is too simplistic to expect a general improvement in pregnancy outcomes and neurodevelopment of the offspring based on this criterion. Several large prospective trials in different countries such as the USA, UK and The Netherlands will hopefully help to clarify these questions in the future.
Declaration of interest

The authors declare that there is no conflict of interest that could be perceived as prejudicing the impartiality of the research reported.

\section{Funding}

This research did not receive any specific grant from any funding agency in the public, commercial or not-for-profit sector.

\section{References}

1 Garber JR, Cobin RH, Gharib H, Hennessey JV, Klein I, Mechanick JI, Pessah-Pollack R, Singer PA, Woeber KA \& American Association of Clinical Endocrinologists and American Thyroid Association Taskforce on Hypothyroidism in Adults. Clinical practice guidelines for hypothyroidism in adults: cosponsored by the American Association of Clinical Endocrinologists and the American Thyroid Association. Endocrine Practice 201218 988-1028. (doi:10.4158/EP12280.GL)

2 De Groot L, Abalovich M, Alexander EK, Amino N, Barbour L, Cobin RH, Eastman CJ, Lazarus JH, Luton D, Mandel SJ et al. Management of thyroid dysfunction during pregnancy and postpartum: an Endocrine Society clinical practice guideline. Journal of Clinical Endocrinology and Metabolism 201297 2543-2565. (doi:10.1210/jc.2011-2803)

3 Lazarus J, Brown RS, Daumerie C, Hubalewska-Dydejczyk A, Negro R \& Vaidya B. European Thyroid Association guidelines for the management of subclinical hypothyroidism in pregnancy and in children. European Thyroid Journal 20143 76-94. (doi:10.1159/000362597)

4 Stagnaro-Green A, Abalovich M, Alexander E, Azizi F, Mestman J, Negro R, Nixon A, Pearce EN, Soldin OP, Sullivan S et al. Guidelines of the American Thyroid Association for the diagnosis and management of thyroid disease during pregnancy and postpartum. Thyroid 201121 1081-1125. (doi:10.1089/thy.2011.0087)

5 Männistö T, Mendola P, Grewal J, Xie Y, Chen Z \& Laughon SK. Thyroid diseases and adverse pregnancy outcomes in a contemporary US cohort. Journal of Clinical Endocrinology and Metabolism 201398 2725-2733. (doi:10.1210/jc.2012-4233)

6 Abalovich M, Amino N, Barbour LA, Cobin RH, De Groot LJ, Glinoer D, Mandel SJ \& Stagnaro-Green A. Management of thyroid dysfunction during pregnancy and postpartum: an Endocrine Society clinical practice guideline. Journal of Clinical Endocrinology and Metabolism 2007 92 (8 Suppl) 1-47. (doi:10.1210/jc.2007-0141)

7 Laurberg P, Andersen SL, Pedersen IB, Andersen S \& Carlé A. Screening for overt thyroid disease in early pregnancy may be preferable to searching for small aberrations in thyroid function tests. Clinical Endocrinology 201379 297-304. (doi:10.1111/cen.12232)

8 Pop VJ, Broeren M \& Wiersinga WM. The attitude towards hypothyroidism during early gestation: time for a change of mind? Thyroid 201424 154-156. (doi:10.1089/thy.2014.0007)

9 Chan S \& Boelaert K. Optimal management of hypothyroidism, hypothyroxinaemia and euthyroid TPO antibody positivity preconception and in pregnancy. Clinical Endocrinology 201582 313-326. (doi:10.1111/cen.12605)

10 Medici M, de Rijke YB, Peeters RP, Visser W, de Muinck Keizer-Schrama SM, Jaddoe VV, Hofman A, Hooijkaas H, Steegers EA, Tiemeier H et al. Maternal early pregnancy and newborn thyroid hormone parameters: the Generation R study. Journal of Clinical Endocrinology and Metabolism 201297 646-652. (doi:10.1210/jc.2011-2398)

11 Li C, Shan Z, Mao J, Wang W, Xie X, Zhou W, Li C, Xu B, Bi L, Meng T et al. Assessment of thyroid function during first-trimester pregnancy: what is the rational upper limit of serum TSH during the first trimester in Chinese pregnant women? Journal of Clinical Endocrinology and Metabolism 201499 73-79. (doi:10.1210/jc.2013-1674) 
12 Carlé A, Laurberg P, Pedersen IB, Knudsen N, Perrild H, Ovesen L, Rasmussen LB \& Jorgensen T. Epidemiology of subtypes of hypothyroidism in Denmark. European Journal of Endocrinology 2006 154 21-28.

13 Medici M, Ghassabian A, Visser W, de Muinck Keizer-Schrama SM, Jaddoe VW, Visser WE, Hooijkaas H, Hofman A, Steegers EA, Bongers-Schokking JJ et al. Women with high early pregnancy urinary iodine levels have an increased risk of hyperthyroid newborns: the population-based Generation R study. Clinical Endocrinology 201480 598-606. (doi:10.1111/cen.12321)

14 Glinoer D, de Nayer P, Bourdoux P, Lemone M, Robyn C, van Steirteghem A, Kinthaert J \& Lejeune B. Regulation of maternal thyroid during pregnancy. Journal of Clinical Endocrinology and Metabolism 1990 71 276-287. (doi:10.1210/jcem-71-2-276)

15 Glinoer D, De Nayer P, Robyn C, Lejeune B, Kinthaert J \& Meuris S. Serum levels of intact human chorionic gonadotropin (HCG) and its free alpha and beta subunits, in relation to maternal thyroid stimulation during normal pregnancy. Journal of Endocrinological Investigation 199316 881-888. (doi:10.1007/BF03348950)

16 Moleti M, Di Bella B, Giorgianni G, Mancuso A, De Vivo A, Alibrandi A, Trimarchi F \& Vermiglio F. Maternal thyroid function in different conditions of iodine nutrition in pregnant women exposed to mild-moderate iodine deficiency: an observational study. Clinical Endocrinology 201174 762-768. (doi:10.1111/j.1365-2265.2011.04007.x)

17 Haddow JE, Knight GJ, Palomaki GE, McClain MR \& Pulkkinen AJ. The reference range and within-person variability of thyroid stimulating hormone during the first and second trimesters of pregnancy. Journal of Medical Screening 200411 170-174. (doi:10.1258/0969141042467340)

18 Lambert-Messerlian G, McClain M, Haddow JE, Palomaki GE Canick JA, Cleary-Goldman J, Malone FD, Porter TF, Nyberg DA, Bernstein $P$ et al. First- and second-trimester thyroid hormone reference data in pregnant women: a FaSTER (First- and Second-Trimester Evaluation of Risk for aneuploidy) Research Consortium study. American Journal of Obstetrics and Gynecology 2008199 62.e1-62.e6. (doi:10.1016/j.ajog.2007.12.003)

19 Weeke J, Dybkjaer L, Granlie K, Eskjaer Jensen S, Kjaerulff E, Laurberg P \& Magnusson B. A longitudinal study of serum TSH, and total and free iodothyronines during normal pregnancy. Acta Endocrinologica 1982 101 531-537.

20 Aboul-Khair SA, Crooks J, Turnbull AC \& Hytten FE. The physiological changes in thyroid function during pregnancy. Clinical Science 196427 195-207.

21 Davison JM \& Hytten FE. Glomerular filtration during and after pregnancy. Journal of Obstetrics and Gynaecology of the British Commonwealth 197481 588-595. (doi:10.1111/j.1471-0528.1974.tb00522.x)

22 Brabant G, Bergmann P, Kirsch CM, Köhrle J, Hesch RD \& von zur Mühlen A. Early adaptation of thyrotropin and thyroglobulin secretion to experimentally decreased iodine supply in man. Metabolism 199241 1093-2006. (doi:10.1016/0026-0495(92)90291-H)

23 Bray GA. Increased sensitivity of the thyroid in iodine-depleted rats to the goitrogenic effects of thyrotropin. Journal of Clinical Investigation 196847 1640-1647. (doi:10.1172/JCI105855)

24 Pisarev M \& Gärtner R. Autoregulatory actions of iodine. In The Thyroid, pp 85-90. Eds LE Braverman \& RD Utiger RD. Philadelphia, PA: LippincottWilliams \& Wilkins, 2000.

25 Studer H \& Derwahl M. Mechanisms of nonneoplastic endocrine hyperplasia - a changing concept: a review focused on the thyroid gland. Endocrine Reviews 199516 411-426.

26 Johner SA, Thamm M, Stehle P, Nöthlings U, Kriener E, Völzke H, Gärtner R \& Remer T. Interrelations between thyrotropin levels and iodine status in thyroid-healthy children. Thyroid 201424 1071-1079. (doi:10.1089/thy.2013.0480)

27 Joung JY, Cho YY, Park SM, Kim TH, Kim NK, Sohn SY, Kim SW \& Chung JH. Effect of iodine restriction on thyroid function in subclinical hypothyroid patients in an iodine-replete area: a long period observation in a large-scale cohort. Thyroid 201424 1361-1368. (doi:10.1089/thy.2014.0046)
28 Sang Z, Wei W, Zhao N, Zhang G, Chen W, Liu H, Shen J, Liu J, Yan Y \& Zhang W. Thyroid dysfunction during late gestation is associated with excessive iodine intake in pregnant women. Journal of Clinical Endocrinology and Metabolism 201297 E1363-E1369. (doi:10.1210/ jc.2011-3438)

29 Springer D, Bartos V \& Zima T. Reference intervals for thyroid markers in early pregnancy determined by 7 different analytical systems. Scandinavian Journal of Clinical and Laboratory Investigation $2014 \mathbf{7 4}$ 95-101. (doi:10.3109/00365513.2013.860617)

30 Bestwick JP, John R, Maina A, Guaraldo V, Joomun M, Wald NJ \& Lazarus JH. Thyroid stimulating hormone and free thyroxine in pregnancy: expressing concentrations as multiples of the median (MoMs). Clinica Chimica Acta 2014430 33-37. (doi:10.1016/j.cca.2013.12.030)

31 Korevaar TI, Medici M, de Rijke YB, Visser W, de Muinck Keizer-Schrama SM, Jaddoe VW, Hofman A, Ross HA, Visser WE, Hooijkaas $\mathrm{H}$ et al. Ethnic differences in maternal thyroid parameters during pregnancy: the Generation R study. Journal of Clinical Endocrinology and Metabolism 201398 3678-3686. (doi:10.1210/jc.2013-2005)

32 Männistö T, Surcel HM, Ruokonen A, Väräsmäki M, Pouta A, Bloigu A, Järvelin MR, Hartikainen AL \& Suvanto E. Early pregnancy reference intervals of thyroid hormone concentrations in a thyroid antibodynegative pregnant population. Thyroid 201121 291-298. (doi:10.1089/ thy.2010.0337)

33 Sapin R, D'Herbomez M \& Schlienger JL. Free thyroxine measured with equilibrium dialysis and nine immunoassays decreases in late pregnancy. Clinical Laboratory 200450 581-584.

34 Feldt-Rasmussen U, Bliddal Mortensen AS, Rasmussen AK, Boas M, Hilsted L \& Main K. Challenges in interpretation of thyroid function tests in pregnant women with autoimmune thyroid disease. Journal of Thyroid Research 20112011 598712. (doi:10.4061/2011/598712)

35 Soldin OP, Chung SH \& Colie C. The use of TSH in determining thyroid disease: how does it impact the practice of medicine in pregnancy? Journal of Thyroid Research 20132013148157. (doi:10.1155/2013/148157)

36 Krassas GE, Poppe K \& Glinoer D. Thyroid function and human reproductive health. Endocrine Reviews 201031 702-755. (doi:10.1210/er.2009-0041)

37 Hirsch D, Levy S, Nadler V, Kopel V, Shainberg B \& Toledano Y. Pregnancy outcomes in women with severe hypothyroidism. European Journal of Endocrinology 2013169 313-320. (doi:10.1530/EJE-13-0228)

38 Negro R, Schwartz A, Gismondi R, Tinelli A, Mangieri T \& StagnaroGreen A. Increased pregnancy loss rate in thyroid antibody negative women with TSH levels between 2.5 and 5.0 in the first trimester of pregnancy. Journal of Clinical Endocrinology and Metabolism 201095 E44-E48. (doi:10.1210/jc.2010-0340)

39 Cleary-Goldman J, Malone FD, Lambert-Messerlian G, Sullivan L, Canick J, Porter TF, Luthy D, Gross S, Bianchi DW, D'Alton ME et al. Maternal thyroid hypofunction and pregnancy outcome. Obstetrics and Gynecology 2008112 85-92. (doi:10.1097/AOG.0b013e3181788dd7)

40 Thangaratinam S, Tan A, Knox E, Kilby MD, Franklyn J \& Coomarasamy A. Association between thyroid autoantibodies and miscarriage and preterm birth: meta-analysis of evidence. BMJ 2011 342 d2616. (doi:10.1136/bmj.d2616)

41 Prummel MF \& Wiersinga WM. Thyroid autoimmunity and miscarriage. European Journal of Endocrinology 2004150 751-755. (doi:10.1530/eje.0.1500751)

42 Redman CW \& Sargent IL. Immunology of pre-eclampsia. American Journal of Reproductive Immunology 201063 534-543. (doi:10.1111/j. 1600-0897.2010.00831.x)

43 Perricone C, de Carolis C \& Perricone R. Pregnancy and autoimmunity: a common problem. Best Practice \& Research. Clinical Rheumatology 2012 26 47-60. (doi:10.1016/j.berh.2012.01.014)

44 Boklage CE. Survival probability of human conceptions from fertilization to term. International Journal of Fertility 199035 75, 79-80, 81-94.

45 Negro R, Formoso G, Mangieri T, Pezzarossa A, Dazzi D \& Hassan H. Levothyroxine treatment in euthyroid pregnant women with 
autoimmune thyroid disease: effects on obstetrical complications. Journal of Clinical Endocrinology and Metabolism 200691 2587-2591. (doi:10.1210/jc.2005-1603)

46 Lepoutre T, Debiève F, Gruson D \& Daumerie C. Reduction of miscarriages through universal screening and treatment of thyroid autoimmune diseases. Gynecologic and Obstetric Investigation $20127 \mathbf{4}$ 265-273. (doi:10.1159/000343759)

47 Wang S, Teng WP, Li JX, Wang WW \& Shan ZY. Effects of maternal subclinical hypothyroidism on obstetrical outcomes during early pregnancy. Journal of Endocrinological Investigation 201235 322-325. (doi:10.3275/7772)

48 Bernardi LA, Cohen RN \& Stephenson MD. Impact of subclinical hypothyroidism in women with recurrent early pregnancy loss. Fertility and Sterility 2013100 1326-1331. (doi:10.1016/j.fertnstert. 2013.07.1975)

49 Kim CH, Ahn JW, Kang SP, Kim SH, Chae HD \& Kang BM. Effect of levothyroxine treatment on in vitro fertilization and pregnancy outcome in infertile women with subclinical hypothyroidism undergoing in vitro fertilization/intracytoplasmic sperm injection. Fertility and Sterility 201195 1650-1654. (doi:10.1016/j.fertnstert. 2010.12.004)

50 Abalovich M, Gutierrez S, Alcaraz G, Maccallini G, Garcia A \& Levalle O. Overt and subclinical hypothyroidism complicating pregnancy. Thyroid 200212 63-68. (doi:10.1089/105072502753451986)

51 Lazarus JH, Bestwick JP, Channon S, Paradice R, Maina A, Rees R, Chiusano E, John R, Guaraldo V, George LM et al. Antenatal thyroid screening and childhood cognitive function. New England Journal of Medicine 2012366 493-501. (doi:10.1056/NEJMoa1106104)

52 Taylor PN, Minassian C, Rehman A, Iqbal A, Shazli Draman M, Hamilton W, Dunlop D, Robinson A, Vaidya B, Lazarus JH et al. TSH levels and risk of miscarriage in women on long-term levothyroxine: a community-based study. Journal of Clinical Endocrinology and Metabolism 201499 3895-3902. (doi:10.1210/jc.2014-1954)

53 Hallengren B, Lantz M, Andreasson B \& Grennert L. Pregnant women on thyroxine substitution are often dysregulated in early pregnancy. Thyroid 200919 391-394. (doi:10.1089/thy.2008.0206)

54 Kilby MD, Verhaeg J, Gittoes N, Somerset DA, Clark PM \& Franklyn JA. Circulating thyroid hormone concentrations and placental thyroid hormone receptor expression in normal human pregnancy and pregnancy complicated by intrauterine growth restriction (IUGR). Journal of Clinical Endocrinology and Metabolism 199883 2964-2971. (doi:10.1210/jcem.83.8.5002)

55 Vasilopoulou E, Loubière LS, Lash GE, Ohizua O, McCabe CJ, Franklyn JA, Kilby MD \& Chan SY. Triiodothyronine regulates angiogenic growth factor and cytokine secretion by isolated human decidual cells in a cell-type specific and gestational age-dependent manner. Human Reproduction 201429 1161-1172. (doi:10.1093/ humrep/deu046)

56 Oki N, Matsuo H, Nakago S, Murakoshi H, Laoag-Fernandez JB \& Maruo T. Effects of 3,5,3'-triiodothyronine on the invasive potential and the expression of integrins and matrix metalloproteinases in cultured early placental extravillous trophoblasts. Journal of Clinical Endocrinology and Metabolism 200489 5213-5221. (doi:10.1210/jc. 2004-0352)

57 Patel J, Landers K, Li H, Mortimer RH \& Richard K. Delivery of maternal thyroid hormones to the fetus. Trends in Endocrinology and Metabolism 201122 164-170. (doi:10.1016/j.tem.2011.02.002)

$58 \mathrm{Li} \mathrm{H}$, Patel J, Mortimer RH \& Richard K. Ontogenic changes in human placental sodium iodide symporter expression. Placenta 201233 946-948. (doi:10.1016/j.placenta.2012.08.002)

59 Andersen SL, Nøhr SB, Wu CS, Olsen J, Pedersen KM \& Laurberg P. Thyroglobulin in smoking mothers and their newborns at delivery suggests autoregulation of placental iodide transport overcoming thiocyanate inhibition. European Journal of Endocrinology 2013168 723-731. (doi:10.1530/EJE-12-0759)
60 Loubière LS, Vasilopoulou E, Glazier JD, Taylor PM, Franklyn JA, Kilby MD \& Chan SY. Expression and function of thyroid hormone transporters in the microvillous plasma membrane of human term placental syncytiotrophoblast. Endocrinology 2012153 6126-6135. (doi:10.1210/en.2012-1753)

61 Sun YN, Liu YJ, Zhang L, Ye Y, Lin LX, Li YM, Yan YQ \& Chen ZP. Expression of organic anion transporting polypeptide $1 \mathrm{c} 1$ and monocarboxylate transporter 8 in the rat placental barrier and the compensatory response to thyroid dysfunction. PLOS ONE 20149 e96047. (doi:10.1371/journal.pone.0096047)

62 Deng WB, Liang XH, Liu JL \& Yang ZM. Regulation and function of deiodinases during decidualization in female mice. Endocrinology 2014 155 2704-2717. (doi:10.1210/en.2014-1015)

63 Aw DK, Sinha RA, Tan HC, Loh LM, Salvatore D \& Yen PM. Studies of molecular mechanisms associated with increased deiodinase 3 expression in a case of consumptive hypothyroidism. Journal of Clinical Endocrinology and Metabolism 201499 3965-3971. (doi:10.1210/jc. 2013-3408)

64 Chan S, Kachilele S, Hobbs E, Bulmer JN, Boelaert K, McCabe CJ, Driver PM, Bradwell AR, Kester M, Visser TJ et al. Placental iodothyronine deiodinase expression in normal and growth-restricted human pregnancies. Journal of Clinical Endocrinology and Metabolism 200388 4488-4495. (doi:10.1210/jc.2003-030228)

65 Huang SA, Dorfman DM, Genest DR, Salvatore D \& Larsen PR. Type 3 iodothyronine deiodinase is highly expressed in the human uteroplacental unit and in fetal epithelium. Journal of Clinical Endocrinology and Metabolism 200388 1384-1388. (doi:10.1210/jc.2002-021291)

66 Loubière LS, Vasilopoulou E, Bulmer JN, Taylor PM, Stieger B, Verrey F, McCabe CJ, Franklyn JA, Kilby MD \& Chan SY. Expression of thyroid hormone transporters in the human placenta and changes associated with intrauterine growth restriction. Placenta 201031 295-304. (doi:10.1016/j.placenta.2010.01.013)

67 Hernandez A, Martinez ME, Fiering S, Galton VA \& St Germain D. Type 3 deiodinase is critical for the maturation and function of the thyroid axis. Journal of Clinical Investigation 2006116 476-484. (doi:10.1172/ JCI26240)

68 Tonyushkina KN, Shen MC, Ortiz-Toro T \& Karlstrom RO. Embryonic exposure to excess thyroid hormone causes thyrotrope cell death. Journal of Clinical Investigation $2014 \mathbf{1 2 4} 321-327$. (doi:10.1172/ JCI70038)

69 Mortimer RH, Galligan JP, Cannell GR, Addison RS \& Roberts MS. Maternal to fetal thyroxine transmission in the human term placenta is limited by inner ring deiodination. Journal of Clinical Endocrinology and Metabolism 199681 2247-2249.

70 Thorpe-Beeston JG, Nicolaides KH, Felton CV, Butler J \& McGregor AM. Maturation of the secretion of thyroid hormone and thyroidstimulating hormone in the fetus. New England Journal of Medicine 1991 324 532-536. (doi:10.1056/NEJM199102213240805)

71 Vulsma T, Gons MH \& de Vijlder JJ. Maternal-fetal transfer of thyroxine in congenital hypothyroidism due to a total organification defect or thyroid agenesis. New England Journal of Medicine 1989321 13-16. (doi:10.1056/NEJM198907063210103)

72 Franco B, Laura F, Sara N \& Salvatore G. Thyroid function in small for gestational age newborns: a review. Journal of Clinical Research in Pediatric Endocrinology 20135 (Suppl 1) 2-7. (doi:10.4274/jcrpe.846)

73 Spremovic-Radjenovic S, Gudovic A, Lazovic G, Marinkovic J, Radunovic N \& Ljubic A. Fetal free thyroxine concentrations in pregnant women with autoimmune thyroid disease. Journal of Clinical Endocrinology and Metabolism 201297 4014-4021. (doi:10.1210/jc. 2012-1392)

74 Blazer S, Moreh-Waterman Y, Miller-Lotan R, Tamir A \& Hochberg Z. Maternal hypothyroidism may affect fetal growth and neonatal thyroid function. Obstetrics and Gynecology 2003102 232-241. (doi:10.1016/ S0029-7844(03)00513-1)

75 Shields BM, Knight BA, Hill A, Hattersley AT \& Vaidya B. Fetal thyroid hormone level at birth is associated with fetal growth. Journal of Clinical 
Endocrinology and Metabolism 201196 E934-E938. (doi:10.1210/jc. 2010-2814)

76 Vaidya B, Campbell V, Tripp JH, Spyer G, Hattersley AT \& Ellard S. Premature birth and low birth weight associated with nonautoimmune hyperthyroidism due to an activating thyrotropin receptor gene mutation. Clinical Endocrinology 200460 711-718. (doi:10.1111/j.13652265.2004.02040.x)

77 Medici M, Timmermans S, Visser W, de Muinck Keizer-Schrama SM, Jaddoe VW, Hofman A, Hooijkaas H, de Rijke YB, Tiemeier H, Bongers-Schokking JJ et al. Maternal thyroid hormone parameters during early pregnancy and birth weight: the Generation R study. Journal of Clinical Endocrinology and Metabolism 201398 59-66. (doi:10.1210/ jc.2012-2420)
78 Andersen SL, Olsen J, Wu CS \& Laurberg P. Low birth weight in children born to mothers with hyperthyroidism and high birth weight in hypothyroidism, whereas preterm birth is common in both conditions: a Danish National Hospital Register study. European Thyroid Journal 20132 135-144. (doi:10.1159/000350513)

79 Pearce SH, Brabant G, Duntas LH, Monzani F, Peeters RP, Razvi S \& Wemeau JL. ETA guideline: management of subclinical hypothyroidism. European Thyroid Journal 20132 215-228. (doi:10.1159/ 000356507)

80 Abdel-Rahman AH, Aly Abbassy H \& Abbassy AA. Improved in vitro fertilization outcomes after treatment of subclinical hypothyroidism in infertile women. Endocrine Practice 201016 792-797. (doi:10.4158/ EP09365.OR)

Received 19 November 2014

Revised version received 18 January 2015

Accepted 3 February 2015 